\title{
Gambaran Klinis dan Karakteristik Neonatus dari Ibu Terkonfimasi Covid-2019 di Rumah Sakit Dr. Soetomo
}

Risa Etika, Kartika Darma Handayani, Setya Mithra Hartiastuti, Virani Diana, Aminuddin Harahap, Oktavian Prasetya, Melinda Masturina

Departemen Ilmu Kesehatan Anak Fakultas Kedokteran Universitas Airlangga/Rumah Sakit Dr. Soetomo, Surabaya, Indonesia

Latar belakang. Penyakit Coronavirus 2019 (COVID-19) merupakan penyakit yang pertama kali dilaporkan di Wuhan, Cina dan telah menyebar ke seluruh dunia. Data ibu hamil dan bayi baru lahir belum banyak dipublikasikan.

Tujuan. Untuk mendeskripsikan gambaran dan karakteristik klinis neonatus yang lahir dari ibu dengan infeksi severe acute respiratory syndrome-coronavirus (SARS-CoV-2) perinatal.

Metode. Penelitian ini merupakan penelitian retrospektif yang dilaksanakan di ruang perawatan neonatal intensive care unit (NICU) Rumah Sakit Umum Daerah Dr.Soetomo Surabaya pada tanggal April - Oktober 2020. Populasi adalah neonatus yang lahir dari ibu terkonfimasi COVID-19 di di Rumah Sakit Dr. Soetomo Surabaya. Data diperoleh dari rekam medik.

Hasil. Total terdapat $109 \mathrm{ibu}$ dengan hasil pemeriksaan positif reverse transcription - polymerase chain reaction (RT PCR) COVID-19, dan hanya 2 bayi dengan hasil RT-PCR COVID-19 positif. Usia rata-rata ibu hamil 28 5 ,9 tahun. Sebanyak 29 bayi (26.61\%) lahir kurang bulan. Cara persalinan didominasi oleh sectio caesaria sebanyak 64 ibu hamil (58,72\%). Terdapat 23 bayi (21,11\%) lahir dengan berat badan lahir < 2500 gram dan 3 bayi dengan hasil negatif RT-PCR COVID-19 meninggal.

Kesimpulan. Saat ini belum terbukti adanya penularan secara vertikal COVID 19, sementara itu transmisi horizontal diperkirakan sebagai sumber infeksi pada neonatus. Penerapan protokol kesehatan terbukti efektif mencegah infeksi terhadap neonatus. Sari Pediatri 2021;22(5):285-9

Kata kunci: ibu konfirm COVID-19, RT PCR, luaran klinis neonatus, karakteristik klinis

\section{Clinical Outcomes and Characteristics of Neonate with Mother Coronavirus Disease-2019 (COVID-2019) Confirmed at The Dr. Soetomo Hospital}

Risa Etika, Kartika Darma Handayani, Setya Mithra Hartiastuti, Virani Diana, Aminuddin Harahap, Oktavian Prasetya, Melinda Masturina

Background. Coronavirus disease 2019 (COVID-19) is a disease that was first reported in Wuhan, China. This disease has spread throughout the world. Data about this disease on pregnant women and neonates have not been widely published

Objective. To describe clinical outcomes and characteristics of the neonate that born to mothers with perinatal severe acute respiratory syndrome-coronavirus (SARS-CoV-2) infection.

Methods. It was a retrospective study conducted in the neonatal intensive care unit (NICU) of the Dr. Soetomo General Hospital, Surabaya on April - October 2020. The population was neonates with mothers confirmed COVID-19. Data were obtained from medical records.

Result. There were 109 mothers had the positive result of COVID-19 reverse transcription-polymerase chain reaction (RT PCR) and only 2 infants with positive results. The mean age of the mother was $28 \pm 5.9$ years. Twenty-nine infants $(26.61 \%)$ were born preterm. Sixty-four infants $(58.72 \%)$ were delivered by caesarean section. There were 23 infants $(21.11 \%)$ were born with birth weight $<2500$ grams and only 3 infants with negative result of COVID-19 RT-PCR were dead.

Conclusion. There is no strong evidence about vertical transmission of COVID-19, meanwhile horizontal transmission is thought to be the source of infection in neonates. The application of health protocols has been proven to be effective in preventing infection in neonates. Sari Pediatri 2021;22(5):285-9

Keywords: confirmed positive COVID-19 mother, RT PCR, neonates clinical outcome, clinical characteristics

Alamat korespondensi: Risa Etika. Departemen Ilmu Kesehatan Anak Fakultas Kedokteran Universitas Airlangga/Rumah Sakit Dr.Soetomo. Jl. Mayjen Prof. Dr. Moestopo No.47, Surabaya. Kode pos 60132. Email: risa_etika@yahoo.com 
Risa Etika dkk: Gambaran klinis dan karakteristik neonatus dari ibu terkonfimasi Covid-19

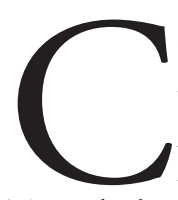

oronavirus disease 2019 (COVID-19) merupakan penyakit yang dilaporkan pertama kali pada tanggal 31 Desember 2019 di daerah Wuhan, provinsi Hubei, Tiongkok dan mewabah di seluruh dunia. Penyakit ini disebabkan oleh virus Severe Acute Respiratory Syndrome Coronavirus-2 (SARS-CoV-2). ${ }^{1}$ Data dari World Health Organization (WHO) tanggal 7 Maret 2010 didapatkan kasus konfirmasi 90.870 dengan total kematian 3.112 orang. Berdasarkan data per tanggal 14 Februari 2020, angka mortalitas di seluruh dunia sebesar 2,1\%, sebanyak 4,9\% di kota Wuhan dan di provinsi Hubei sebesar 3,1\%. Di Indonesia per tanggal 14 Maret 2020, terkonfirmasi 96 kasus COVID-19 dengan jumlah kematian 6 orang dan menjadi negara ke-65 yang positif konfirmasi COVID-19. Secara keseluruhan, tingkat mortalitas dari COVID-19 masih lebih kecil jika dibandingkan dengan kejadian luar biasa oleh Coronavirus tipe lain, seperti Severe Acute Respiratory Syndrome-coronavirus (SARS-CoV) dan Middle East Respiratory Syndrome-coronavirus (MERSCoV), berturut-turut $10 \%$ dan $40 \% .^{2}$

Data mengenai wanita hamil dan bayi baru lahir belum banyak dipublikasikan. Untuk infeksi virus lainnya, kehamilan meningkatkan risiko morbiditas, dengan risiko penularan vertikal yang dijelaskan dengan baik dan terdapat keluaran klinis yang buruk untuk bayi baru lahir. Namun, penelitian yang mengevaluasi potensi penularan vertikal dan/atau paska kelahiran terhadap SARS-CoV-2 jumlahnya masih sangat sedikit, ukuran sampel yang kecil, dan terutama berasal dari Tiongkok sehingga hasilnya mungkin tidak dapat digeneralisasikan untuk semua populasi. Meskipun beberapa penelitian tidak menunjukkan bukti penularan vertikal, beberapa penelitian lain menggambarkan bayi baru lahir dengan SARS-CoV-2 yang terdeteksi melalui uji swab PCR nasofaring dan penyakit pernapasan ringan atau pneumonia dapat sembuh sendiri. ${ }^{1,3}$ Studi Breslin $\mathrm{dkk}^{4}$ yang mengevaluasi periode 2 minggu awal infeksi SARS-CoV-2 pada ibu hamil menunjukkan bahwa tidak ada bukti penularan vertikal setelah melahirkan. Mengingat penyebaran SARS-CoV-2 yang terus berlanjut di seluruh dunia, penyebaran pada ibu hamil dan bayi mereka yang baru lahir menjadi sangat penting. Hal tersebut berkaitan dengan kebijakan rumah sakit dalam manajemen ibu hamil dengan infeksi SARS-CoV2 dan bayinya. ${ }^{3}$

Di sini kami menyajikan pengalaman mengenai ibu yang positif SARS-CoV-2 dan bayi mereka yang baru lahir di RSUD Dr. Soetomo Surabaya selama 6 bulan pertama pandemi COVID-19. Tujuan dari penelitian ini adalah untuk mendeskripsikan penularan vertikal pada bayi baru lahir yang lahir dari ibu dengan infeksi SARS-CoV-2 perinatal dan melaporkan karakteristik klinis dan perjalanan klinis neonatus segera setelah melahirkan

\section{Metode}

Penelitian ini merupakan penelitian retrospektif di Rumah Sakit Pendidikan dan Pusat Rujukan RSUD Dr. Soetomo Surabaya. Pengambilan sampel pasien dimulai April hingga Oktober 2020 di unit perawatan intensif neonatal atau Neonatal Intensive Care Units (NICU). Selama pandemi, seluruh ibu hamil yang dirawat di RSUD dr. Soetomo menjalani skrining COVID-19 sesuai dengan ketentuan Kementerian Kesehatan Republik Indonesia. Semua neonatus yang lahir dari ibu positif COVID-19 berdasarkan hasil usap RT-PCR diikutsertakan dalam penelitian ini. Neonatus yang lahir dari ibu positif COVID-19 akan menjalani swab RT PCR minimal satu kali dalam 24 jam pertama,

Diagnosis ibu dan neonatus dengan infeksi COVID-19 diperoleh dari hasil pemeriksaan RTPCR dari usap nasofaring yang dilaksanakan di Laboratorium Mikrobiologi RSUD Dr. Soetomo Surabaya. Pencatatan data pasien meliputi hasil pemeriksaan RT-PCR ibu dan bayi, usia ibu, usia kehamilan, cara persalinan, berat badan lahir bayi, asfiksia atau tidak, dan mortalitas. Data tersebut diperoleh melalui rekam medis. Penelitian ini disetujui oleh komite etik RSUD Dr. Soetomo Surabaya. Pengolahan dan analisis data dengan menggunakan Statistical Product and Service Solution (SPSS) for Windows versi 24.0

\section{Hasil}

Dalam penelitian ini didapatkan 109 ibu hamil dengan hasil RT-PCR COVID-19 positif. Pada pemeriksaan usap nasofaring RT-PCR neonatus, ternyata sebagian besar menunjukkan hasil negatif infeksi COVID-19, yaitu 107 neonatus (98,2\%), sedangkan yang positif hanya 2 neonatus $(1,8 \%)$. Usia 
rata-rata ibu hamil adalah $28,9 \pm 5,9$ tahun, hanya 14 $(12,8 \%)$ yang berusia di atas 35 tahun. Rata-rata usia kehamilan ibu dengan COVID-19 adalah 37,1 22,9 minggu, sebagian besar bayi cukup bulan $(73,4 \%)$ sedangkan sisanya adalah bayi prematur $(26,6 \%)$ (Tabel 1).

Kelahiran bayi prematur dibagi menjadi bayi late preterm 32-36 minggu), peripreterm (28-31 minggu), dan extremely preterm (<28 minggu). Dari jumlah bayi prematur, mayoritas $(86,2 \%)$ merupakan bayi prematur terlambat atau late preterm infant dan tidak ditemukan bayi lahir dengan sangat prematur atau extremely preterm infant. Berdasarkan cara persalinan, 64 ibu hamil $(58,7 \%)$ dilakukan operasi caesar, dan sisanya $(41,3 \%)$ dilakukan secara pervaginam. Berat lahir rata-rata neonatus adalah 2,921 \pm 713 gram. Berat badan lahir didominasi oleh berat bada $>2500$ gram, yaitu $86(78,9 \%)$. Kemudian diikuti dengan berat

Tabel 1. Karakteristik ibu

\begin{tabular}{lcc}
\hline Parameter & Rata-rata \pm SD & $\mathrm{n}(\%)$ \\
\hline Usia ibu (tahun) & $28,9 \pm 5,9$ & \\
$\quad \leq 35$ & - & $95(87,2)$ \\
$\quad>35$ & - & $14(12,8)$ \\
Usia kehamilan & $37,1 \pm 2.9$ & \\
(minggu) & - & $29(26,6)$ \\
$\quad<37$ & - & $80(73,4)$ \\
$\quad \geq 37$ & - & \\
Cara persalinan & - & \\
$\quad$ Sectio caesarean & - & $64(58,7)$ \\
$\quad$ Pervaginam & - & $45(41,3)$ \\
\hline
\end{tabular}

Tabel 2. Gambaran klinis dan karakteristik klinis neonatus

\begin{tabular}{lcc}
\hline Parameter & Rata-rata \pm SD & $\mathrm{n}(\%)$ \\
\hline Hasil RT-PCR & & \\
COVID-19 & - & $2(1,8)$ \\
$\quad$ Positif & - & $107(98,2)$ \\
Negatif & & \\
Prematur & - & $25(86,2)$ \\
$\quad$ Late preterm & - & $4(13,8)$ \\
Peri preterm & - & 0 \\
Extremely preterm & $2.921 \pm 713$ & \\
Berat lahir (gram) & - & $86(78,9)$ \\
$\geq 2500$ & - & $21(19,3)$ \\
$1500-2499$ & - & $2(1,8)$ \\
$<1000-1499$ & & 0 \\
$<1000$ & & \\
Luaran klinis & - & $3(2,7)$ \\
Meninggal & - & $106(97,2)$ \\
Hidup &
\end{tabular}

badan lahir 1500-2499 gram sebesar 21 (19,3\%), dan hanya ada dua neonatus dengan berat lahir $<1500$ gram. Dengan demikian, tidak ada berat lahir kurang dari 1000 gram. Dari seluruh bayi yang lahir dari ibu hamil dengan infeksi COVID-19, 3 (2,7\%) meninggal karena gagal napas, $7(6,4 \%)$ pernah mendapat perawatan di NICU akibat asfiksia, prematuritas, atau gangguan pernapasan, dan lainnya $100(90,9 \%)$ dalam kondisi stabil (Tabel 2).

\section{Pembahasan}

Virus SARS-COV-2 masih terus menyebar dan kelompok ibu hamil merupakan salah satu kelompok yang rentan terinfeksi COVID-19. Allotey $\mathrm{dkk}^{5}$ melaporkan bahwa 10\% ibu hamil harus dirawat di rumah sakit dengan indikasi tertentu, setelah dilakukan pemeriksaan RT-PCR ternyata terkonfimasi positif COVID-19. Saat ini masih sedikit bukti yang mendukung mengenai efek COVID-19 saat kehamilan pada bayi baru lahir. Data dari jenis coronavirus sebelumnya (SARS-CoV dan MERS-CoV) menunjukkan bahwa ibu hamil berisiko lebih tinggi untuk menderita penyakit dengan klinis yang lebih berat, morbiditas, dan mortalitas dibandingkan dengan populasi umum. ${ }^{6}$ Fakta mengenai apakah COVID-19 meningkatkan risiko abortus, lahir mati, persalinan prematur, takikardia padajanin, dan gawat janin masih belum diketahui sepenuhnya. Chen $\mathrm{dkk},{ }^{3}$ pada studinya mengenai karakteristik klinis dan patologi plasenta dari tiga ibu hamil terkonfimasi COVID-19, melaporkan bahwa tidak didapatkan asam nukleat SARS-COV-2 yang terdeteksi pada usap plasenta maupun usap tenggorok bayi baru lahir.

Dalam penelitian ini, 109 ibu hamil terkonfirmasi COVID 19, 2 (1,8\%) bayi dinyatakan positif, sedangkan mayoritas 107 (98,2\%) dinyatakan negatif. Sementara Karimi dkk ${ }^{7}$ melaporkan bahwa dari $31 \mathrm{ibu}$ hamil yang melahirkan, tidak ada satupun bayi yang positif. Kesimpulan dari penelitian mereka adalah bahwa hingga saat ini, tidak ada bukti transmisi intrauterin COVID-19. Sheth $\mathrm{dkk}^{8}{ }^{8}$ melakukan telaah terhadap 39 studi yang dipublikasikan dan dilaporkan bahwa dari 326 wanita hamil yang terkonfimasi COVID 19, terdapat 23 bayi baru lahir (7,05\%) terkonfimasi positif dan diperkirakan 3\% infeksi didapatkan melalui transmisi vertikal. Hasil penelitian 
Risa Etika dkk: Gambaran klinis dan karakteristik neonatus dari ibu terkonfimasi Covid-19

ini sesuai dengan beberapa penelitian lain, yaitu jumlah bayi baru lahir yang terkonfirmasi COVID-19 memang sangat rendah (1,8\%). Namun, pada penelitian ini, usap plasenta tidak dilakukan untuk membuktikan transmisi vertikal. Dengan demikian, penelitian lebih lanjut masih diperlukan untuk membuktikan transmisi vertikal atau horizontal.

Sebagian penelitian menunjukkan adanya dugaan transmisi vertikal pada neonatus yang terkonfirmasi COVID 19 yang dilakukan pemeriksaan usap RTPCR pada 48 jam perawatan postpartum dengan proses persalinan sesuai dengan protokol pencegahan COVID 19. ${ }^{8}$ The American Academic of Pediatrics (AAP) merekomendasikan skrining neonatus yang lahir dari ibu terkonfirmasi COVID 19 pada 24 dan 48 jam setelah lahir. Data terbaru menunjukkan bahwa kadar reseptor angiotensin-2 sangat rendah di plasenta sehingga transmisi vertikal tidak mungkin terjadi. Chen $\mathrm{dkk}^{3}$ melaporkan bahwa tidak ada perubahan pada ciri morfologi plasenta dari ibu yang terinfeksi COVID-19, dan tidak ditemukan asam nukleat. Pemeriksaan usap nasofaring neonatus pada 24 dan 48 jam lahir setelah lahir sudah menjadi protokol yang rutin dilakukan di RSUD Dr. Soetomo, Surabaya.

Beberapa publikasi ilmiah telah merekomendasikan tindakan pencegahan yang ketat untuk menghindari penularan horizontal selama resusitasi neonatus dengan ibu yang terkonfirmasi COVID-19 di ruang bersalin. Rekomendasi AAP untuk petugas medis agar menggunakan alat pelindung diri selama resusitasi neonatus termasuk gaun, sarung tangan, masker pernapasan $\mathrm{N}$ 95, dan kacamata pelindung mata atau alat bantu pernapasan penyaring udara. ${ }^{8}$ Penerapan protokol pencegahan infeksi yang ketat saat periode perinatal dapat mengurangi insiden penularan horizontal virus COVID-19 secara bermakna. ${ }^{7}$ Penularan melalui kontak kulit-ke-kulit masih kontroversial sehingga kontak kulit-ke-kulit dapat diizinkan jika ibu menggunakan masker dan mencuci tangan.

Cara persalinan tidak berpengaruh terhadap penularan COVID-19 pada neonatus. ${ }^{9}$ Kalamdani $\mathrm{dkk}^{11}$ melaporkan bahwa persalinan yang dilakukan dengan operasi caesar lebih banyak dibandingkan dengan persalinan normal $(83,3 \%)$. Dalam penelitian ini, $58,7 \%$ bayi lahir dengan operasi caesar, dan $41,3 \%$ lahir pervaginam. Angka operasi caesar ini jauh lebih rendah jika dibandingkan dengan yang dilaporkan oleh Kalamdani dkk. ${ }^{11}$ Pada awal pandemi COVID-19, informasi yang minim mengenai potensi penularan vertikal SARS-CoV-2, berakibat pada kecemasan pada ibu hamil atau dokter kandungan. Hal ini tampak angka kelahiran prematur dan operasi caesar yang tinggi. Meskipun perburukan kondisi ibu dan gawat janin yang terjadi merupakan 50\% dampak kelahiran prematur, tetapi sisanya akibat iatrogenik pada ibu hamil terkonfimasi COVID-19 ringan tanpa adanya keadaan darurat ibu atau janin. Hal ini menunjukkan bahwa tidak mungkin apabila COVID-19 sendiri yang menyebabkan peningkatan risiko kelahiran prematur. ${ }^{12}$ Tingkat kelahiran prematur yang tinggi secara keseluruhan cenderung berkontribusi pada hasil neonatal yang buruk dan menyebabkan peningkatan perawatan di NICU.

Viral pneumonia adalah salah satu penyebab utama morbiditas dan mortalitas pada ibu hamil. ${ }^{13}$ Pneumonia pada ibu hamil dikaitkan dengan berbagai hasil klinis persalinan, seperti ketuban pecah dini, persalinan prematur, kematian janin intra uterine (IUFD), kelahiran dengan berat badan lahir bayi rendah (BBLR), dan kematian neonatal. ${ }^{14}$ Hasil klinis ibu hamil yang terkonfirmasi COVID-19 adalah kematian ibu sebanyak 1,6\%, lahir mati $1,4 \%$, kematian neonatal $1,0 \%$ dan prematuritas $33,7 \% .{ }^{15}$ Studi yang dilakukan oleh De Bernardo $\mathrm{dkk}^{16}$ melaporkan bahwa manifestasi gejala dan tanda klinis infeksi COVID-19 pada neonatus lebih ringan dibandingkan pada pasien dewasa. Gejala utama yang sering muncul, yaitu demam, muntah, batuk, sesak napas dan tidak ada neonatus yang meninggal akibat COVID-19. Hasil pada studi ini didapatkan pada 109 neoantus yang lahir dari ibu terkonfimasi positif COVID-19, 21,1\% bayi lahir dengan berat badan lahir rendah dengan 19,3\% di antaranya 1500-2499 gram, dan $2 \%$ lahir $<1500$ gram. Kelahiran prematur $26,6 \%$, dengan 25 bayi di antaranya lahir dengan usia gestasi 32-36 minggu, dan 4 bayi lahir pada 2831 minggu. Mortalitas neonatus yang lahir dari ibu terkonfimasi positif COVID-19 hanya terdapat 3 kasus $(2,7 \%)$ dengan penyebab kematian yaitu gagal napas. Hasil tersebut lebih rendah jika dibandingkan dengan tingkat mortalitas dan prematuritas yang dilaporkan pada studi Turan dkk. ${ }^{15}$ Studi De Bernardo dkk ${ }^{16}$ tidak menemukan adanya kematian neonatus yang terinfeksi COVID-19. Sampai saat ini, hubungan antara infeksi COVID-19 pada neonatus dan manifestasi klinisnya belum banyak diketahui. 


\section{Kesimpulan}

Pandemi COVID-19 masih menjadi masalah kesehatan di seluruh dunia. Ibu hamil dan neonatus merupakan kelompok yang sangat rentan terhadap penularan COVID-19. Hingga saat ini belum ada bukti penularan COVID-19 secara vertikal pada neonatus, sedangkan penularan horizontal diduga sebagai sumber penularan pada neonatus. Penerapan protokol kesehatan berupa pemakaian masker, cuci tangan dan menjaga jarak terbukti efektif mencegah infeksi pada neonatus. Penelitian lebih lanjut diperlukan untuk memahami cara penularan, gejala dan hasil klinis pada neonatus

\section{Daftar pustaka}

1. Yu N, Li W, Kang Q, dkk. Clinical features and obstetric and neonatal outcomes of pregnant patients with COVID-19 in Wuhan, China: a retrospective, single centre, descriptive study. Lancet Infect Dis 2020; 20:559-64.

2. Favre G, Pomar L, Musso D, Baud D. 2019-nCoV epidemic: what about pregnancies? Lancet 2020;395:e40.

3. Chen H, Guo J, Wang C, dkk. Clinical characteristics and intrauterine vertical transmission potential of COVID-19 infection in nine pregnant women: a retrospective review of medical records. Lancet 2020; 395:809-15.

4. Breslin N, Baptiste C, Gyamfi-Bannerman C, dkk. Coronavirus disease 2019 infection among asymptomatic and symptomatic pregnant women: two weeks of confirmed presentations to an affiliated pair of New York City hospitals. Am J Obstet Ggynecol 2020;2:100-18.

5. Allotey J, Stallings E, Bonet M, dkk. Clinical manifestations, risk factors, and maternal and perinatal outcomes of coronavirus disease 2019 in pregnancy: living systematic review and meta-analysis. BMJ 2020;370:3320.

6. Rasmussen SA, Smulian JC, Lednicky JA, Wen TS, Jamieson DJ. Coronavirus disease 2019 (COVID-19) and pregnancy: what obstetricians need to know. Am J Obstet Gynecol 2020;222:415-26.

7. Karimi-Zarchia,M, Neamatzadehc,H, Dastgheibe SA. Vertical transmission of Coronavirus Disease 19 (COVID-19) from infected pregnant mothers to neonates: a review. Fetal Pediatr Pathol 2020;39:246-50.

8. Sheth S, Shah N, Bhandari V. Outcomes in COVID-19 positive neonates and possibility of viral vertical transmission: a narrative review. Am J Perinatol 2020;37:1208-16.

9. FAQs: management of infants born to mothers with suspected or confirmed COVID-19. Diakses 18 Juni 2020 Didapat dari:https://services.aap.org/en/pages/2019-novel-coronaviruscovid-19-infections/clinicalguidancel faqs-management-ofinfants-born-to-covid-19-mothers/.

10. Chawla D, Chirla D, Dalwai S, dkk. Perinatal-neonatal management of COVID-19 infection -guidelines of the federation of obstetric and gynaecological societies of India (FOGSI), National Neonatology Forum of India (NNF), and Indian Academy of Pediatrics (IAP). Indian Pediatr 2020;57:536-48.

11. Kalamdani P, Kalathingal T, Manerkar S, dkk. Clinical profile of SARS-CoV-2 infected neonates from a tertiary government hospital in Mumbai, India. Diakses 5 Januari 2021. Didapat dari: https://www.indianpediatrics.net/epub102020/RP-00250. $p d f$.

12. Storya L, Simpsonb NAB, David AL, dkk. Reducing the impact of preterm birth: preterm birth commissioning in the United Kingdom. Eur J Obstetr Gynecol Reproduct Biol 2019; 3: 100018.

13. Berkowitz K, LaSala A. Risk factors associated with the increasing prevalence of pneumonia during pregnancy. Am J Obstetr Gynecol 1990;163:981-5.

14. Schwartz DA, Graham AL. Potential maternal and infant outcomes from (Wuhan) Coronavirus 2019-nCoV infecting pregnant women: lessons from SARS, MERS, and other human coronavirus infections. Viruses 2020;12:194.

15. Turan O, Hakim A, Dashraath P. Clinical characteristics, prognostic factors, and maternal and neonatal outcomes of SARS-CoV-2 infection among hospitalized pregnant women: A systematic review. Int J Gynecol Obstet 2020;151:7-16.

16. De Bernardo G, Giordano M, Zollo G, dkk. The clinical course of SARS-CoV-2 positive neonates. J Perinatol 2020;40:146269. 